\title{
FITOREMEDIASI LOGAM KADMIUM (Cd) DARI ASAP ROKOK MENGGUNAKAN TANAMAN PURING (Codiaeum variegatum)
}

\author{
Kurniawati L, Syamsidar HS, Kurnia Ramadani \\ Jurusan Kimia, Fakultas Sains dan Teknologi, UIN Alauddin Makassar
}

\begin{abstract}
Environmental problems in Indonesia even in the world of growing. One of the factors causing the environmental problems with surging smoking habits in society that cause air pollution. One of the pollutants generated from cigarette smoke is a cadmium $(C d)$ metal. One of the efforts made in reducing pollutants in the air, especially $\mathrm{Cd}$ metals is phytoremediation method using plant croton (Codiaeum variegatum). This study aims to determine the ability of plants to absorb Cd metals croton. The method is performed by directly exposure at 3, 6 and 9 days. Instrument used in this study is an atomic absorption spectrophotometer (AAS). The results showed that the croton leaves absorb Cd metal with a maximum concentration of $1,065 \mathrm{mg} / \mathrm{kg}$ on days 9 , so that it can be used as Cd metal phytoremediator.
\end{abstract}

Keyword: Air pollution, cadmium $(C d)$, cigarette smoke, Puring, phytoremediation,

\section{PENDAhULUAN}

Permasalahan lingkungan di Indonesia bahkan di dunia kian bertambah. Salah satu faktor penyebab timbulnya permasalahan lingkungan tersebut dengan melonjaknya kebiasaan merokok pada masyarakat sehingga menyebabkan terjadinya pencemaran udara. Keberlangsungan hidup diperlukan udara yang sehat, namun dengan meningkatnya polusi udara sehingga menyebabkan udara sekitar menjadi tercemar.

Kebiasaan merokok merupakan masalah penting dewasa ini. Rokok oleh sebagian orang sudah menjadi kebutuhan hidup yang tidak bisa ditinggalkan dalam kehidupan sehari-hari. World Health Organization (WHO) pada tahun 2003 menyatakan bahwa rokok merupakan penyebab kematian tiga juta penduduk dunia setiap tahunnya. WHO menetapkan tanggal 31 Mei sebagai "Hari Tanpa Tembakau Sedunia" (World No Tobacco Day).

Konsumsi rokok dan tembakau merupakan salah satu faktor resiko utama timbulnya berbagai penyakit berbahaya seperti stroke, kanker paru-paru, kanker mulut dan kelainan kehamilan. Penyakit-penyakit tersebut saat ini merupakan penyebab kematian utama di dunia, termasuk di Indonesia. Konsumsi tembakau atau rokok membunuh satu orang setiap detik.

Kadmium (Cd) merupakan salah satu logam yang terkandung di dalam rokok yang mana belum diketahui fungsinya secara biologis dan memiliki toksisitas yang tinggi. Semakin tinggi kadar dan semakin lama paparan, maka efek toksik yang diberikan akan lebih besar. Kadmium (Cd) dapat menyebabkan gangguan saluran pencernaan, sedangkan paparan kadmium (Cd) dalam dosis rendah tetapi berulang kali bisa mengakibatkan gangguan fungsi ginjal. 
Kadmium (Cd) pada rokok dapat berkaitan dengan jenis tanah perkebunan tembakau, kondisi penanaman serta penggunaan bahan penyubur tanaman dan pembasmi hama yang berbeda. Salah satu upaya yang dapat dilakukan untuk mengurangi pencemaran udara akibat dari paparan asap rokok yaitu dengan menggunakan metode fitoremediasi. Metode ini sudah banyak digunakan dan terbukti efisien dalam mengurangi pencemaran lingkungan akibat logam berat.

Tanaman puring (Codiaeum varieggatum) merupakan salah satu tanaman hias yang dapat digunakan yang memiliki bentuk dan warna daun yang bervariasi. Tanaman ini mampu mengakumulasi kadmium (Cd). Semakin banyak tanaman yang ditanam akan membantu menurunkan emisi logam berat di udara. Penelitian yang telah dilakukan oleh Yusriani Sapta Dewi dan Indri Hapsari pada tahun 2012 menunjukkan kemampuan tanaman puring (Codiaeum variegatum) dalam menyerap logam $\mathrm{Pb}$ pada Udara Ambien sebesar 22,89\% dan lidah mertua (Sansevieria trifasciata) sebesar $2,91 \%$. Berdasarkan latar belakang tersebut, maka dilakukanlah suatu penelitian mengenai "Fitoremediasi Logam Kadmium (Cd) dari Asap Rokok Menggunakan Tanaman Puring (Codiaeum varieggatum) dengan cara pengasapan langsung”.

\section{Tujuan}

Untuk mengetahui penyerapan logam kadmium dari asap rokok jenis non filter dengan menggunakan tanaman puring (Codiaeum variegatum) sebagai fitoremediator.

\section{METODE PENELITIAN}

\section{Waktu dan Tempat Penelitian}

Penelitian ini dilakukan pada bulan Mei - Oktober 2015 di laboratorium Kimia Anorganik dan laboratorium Riset Fakultas Sains dan Teknologi UIN Alauddin Makassar.

\footnotetext{
Alat dan Bahan

Peralatan yang digunakan seperangkat alat Spektrofotometer Serapan Atom (SSA) merek varian, oven, alat-alat gelas, neraca analitik, hot plate, botol semprot, batang pengaduk, batu didih dan wadah pot bunga.

Bahan-bahan yang digunakan pada penelitian ini yaitu aluminium foil, aquabides $\left(\mathrm{H}_{2} \mathrm{O}\right)$, asam nitrat $\left(\mathrm{HNO}_{3}\right)$ p.a, asam perklorat $\left(\mathrm{HClO}_{4}\right)$ p.a, daun puring (Codiaeum variegatum), kertas saring Whatman no. 42, larutan induk kadmium $\left(\mathrm{Cd}\left(\mathrm{NO}_{3}\right)_{2}\right)$, rokok non filter dan tissu.
} 


\section{Prosedur Kerja}

\section{Proses akumulasi tanaman puring (Codiaeum variegatum)}

Sebelum dilakukan pengasapan secara langsung tanaman puring (Codiaeum variegatum) terlebih dahulu diisolasi selama 2 bulan. Penentuan konsentrasi awal kadmium (Cd) pada daun sebagai pengontrol dilakukan dengan metode spektrofotometer serapan atom (SSA). Kemudian pengasapan langsung dilakukan dengan menggunakan rokok non filter terhadap tanaman puring (Codiaeum variegatum). Rokok yang digunakan sebanyak 1 bungkus (12 batang) per hari. Pengukuran kadar kadmium (Cd) tanaman dilakukan tiap (3, 6 dan 9) hari selama pemaparan. Pengasapan dilakukan dengan menggunakan bantuan alat yang telah dimodifikasi untuk mengeluarkan asap rokok.

\section{Pengambilan Sampel}

Daun puring (Codiaeum variegatum) dipetik sebanyak 28 lembar kemudian ditempatkan di dalam plastik bening dan diteliti di laboratorium Universitas Islam Negeri Alauddin Makassar. Pengambilan sampel dilakukan pada (3, 6 dan 9) hari pemaparan pada pagi hari.

\section{Peparasi sampel}

Sampel yang telah dipetik kemudian dimasukkan ke dalam plastik dan diteliti di laboratorium Anorganik dan Laboratorium Riset. Sampel tersebut dipotong kecil-kecil dan dikeringkan di dalam oven dengan suhu $105{ }^{\circ} \mathrm{C}$ selama 2 jam dan ditimbang sebanyak 2 gram sampel (duplo). Sampel kemudian didestruksi basah menggunakan hot plate dengan menambahkan aquabides $\left(\mathrm{H}_{2} \mathrm{O}\right)$ sebanyak $10 \mathrm{~mL}$, asam nitrat $\left(\mathrm{HNO}_{3}\right)$ p.a sebanyak $2 \mathrm{~mL}$ dan batu didih sampai menghasilkan gas $\mathrm{NO}_{2}$ yang berwarna kecoklatan. Apabila masih menghasilkan asap berwarna kecoklatan maka sampel tersebut didinginkan dan ditambahkan 0,4 $\mathrm{mL}$ asam perklorat $\quad\left(\mathrm{HClO}_{4}\right)$ p.a yang kemudian dipanaskan kembali sampai dihasilkan uap berwarna putih hingga volume berkurang. Setelah itu, didinginkan dan disaring menggunakan kertas saring Whatman no. 42 dan dimasukkan ke dalam labu ukur 50 mL, kemudian diencerkan sampai tanda batas dan dihomogenkan. Sampel siap diukur kadar logam kadmium (Cd) menggunakan Spektrofotometer Serapan Atom (SSA) $\quad(\lambda=228,8 \mathrm{~nm})$. 


\section{HASIL DAN PEMBAHASAN}

Tabel 1. Kandungan kadmium $(\mathrm{Cd})$ yang terserap oleh daun puring dengan cara pengasapan langsung.

\begin{tabular}{|c|c|c|c|c|c|c|c|}
\hline \multirow{2}{*}{$\begin{array}{l}\text { Variasi } \\
\text { Waktu } \\
\text { (Hari) }\end{array}$} & \multicolumn{2}{|c|}{$\begin{array}{c}\begin{array}{c}\text { Absorbansi Cd } \\
(\mathbf{p p m})\end{array} \\
\end{array}$} & \multicolumn{2}{|c|}{$\begin{array}{c}\text { Konsentrasi Cd } \\
(\mathrm{mg} / \mathrm{L})\end{array}$} & \multirow{2}{*}{$\begin{array}{c}\text { Konsentrasi } \\
\text { Rata-Rata } \\
\text { Cd (mg/L) }\end{array}$} & \multirow[t]{2}{*}{$\begin{array}{l}\text { Konsentrasi } \\
\text { Cd (mg/Kg) }\end{array}$} & \multirow{2}{*}{$\begin{array}{c}\text { Cd yang } \\
\text { Terserap } \\
\text { oleh } \\
\text { Daun } \\
(\mathrm{mg} / \mathrm{Kg}) \\
\end{array}$} \\
\hline & 1 & 2 & 1 & 2 & & & \\
\hline 0 & 0,0673 & 0,0627 & 0,0658 & 0,0284 & 0,0471 & 1,1775 & - \\
\hline 3 & 0,0678 & 0,0723 & 0,0698 & 0,1063 & 0,0881 & 2,2025 & 1,025 \\
\hline 6 & 0,0617 & 0,0710 & 0,0203 & 0,0958 & 0,0580 & 1,45 & 0,2725 \\
\hline 9 & 0,0726 & 0,0679 & 0,1088 & 0,0706 & 0,0897 & 2,2425 & 1,065 \\
\hline
\end{tabular}

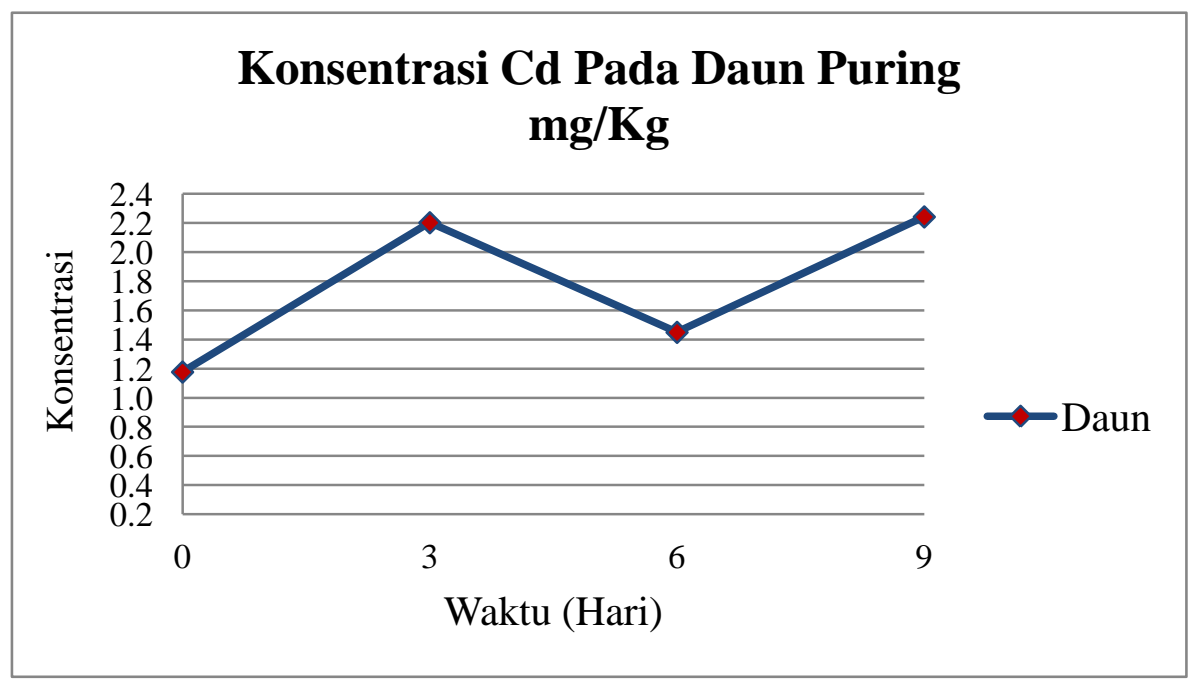

Gambar 1. Penyerapan Cd pada morfologi daun puring

Berdasarkan hasil penelitian diperoleh penyerapan $\mathrm{Cd}$ pada daun puring (Codiaeum variegatum) mengalami penurunan pada hari ke-6 dengan konsentrasi sebesar 0,2725 mg/Kg dan mencapai titik maksimum atau penyerapan kadmium tertinggi pada hari ke- 9 dengan konsentrasi sebesar $1,065 \mathrm{mg} / \mathrm{Kg}$.

\section{Mekanisme Penyerapan Logam Cd oleh Tanaman Puring (Codiaeum variegatum)}

Logam Cd dapat terakumulasi oleh tanaman puring melalui daun. Kandungan klorofil pada daun akan mempengaruhi reaksi fotosintesis. Fotosintesis terjadi pada saat daun melepas uap air dan mengambil $\mathrm{CO}_{2}$ dan gas lainnya termasuk polutan salah satunya $\mathrm{Cd}$ melalui stomata. 
Kadar klorofil yang sedikit tidak akan menjadikan reaksi fotosintesis maksimal, sehingga proses penyerapan Cd juga belum maksimal.

Kerusakan fisik yang terjadi pada daun dapat mempengaruhi proses fotosintesis. Bahan pencemar dapat menyebabkan terjadinya kerusakan fisiologi di dalam tanaman khususnya daun yaitu rusaknya sel atau disintegrasi, pigmentasi jaringan dan plasmolosis. Daun yang tua memiliki kadar klorofil atau stomata yang tinggi yang menyebabkan gugus - $\mathrm{SH}$ pada fitokelatin dengan mudah dapat mengikat logam kadmium melalui proses fotosintesis. Proses fotosintesis akan berlangsung sempurna seiring dengan tingginya kadar klorofil pada daun. Proses fotosintesis tersebut berlangsung melalui stomata daun, di mana ukuran dari stomata sebesar $10 \mu$ x $2-7 \mu$. Sedangkan ukuran dari partikulat $\mathrm{CdO}$ hanya sebesar $0,3 \mu-0,5 \mu$ sehingga $\mathrm{Cd}$ dengan mudah terserap ke dalam jaringan daun melalui proses fotosintesis.

Penyerapan $\mathrm{Cd}$ juga dipengaruhi oleh suatu enzim fitokelatin di dalam daun yang digunakan untuk mengikat logam berat. Fitokelatin merupakan peptida kecil yang mengandung 2 sampai 8 asam amino sistein, sebuah asam glutamat dan sebuah glisin pada ujungnya yang berlawanan. Logam berat $\mathrm{Cd}$ memiliki afinitas yang tinggi terhadap unsur $\mathrm{S}$ yang menyebabkan $\mathrm{Cd}$ menyerang ikatan belerang ( $\mathrm{S}$ ) dalam enzim sehingga enzim yang bersangkutan menjadi tidak aktif.

\section{PENUTUP}

\section{Kesimpulan}

Kesimpulan dari hasil penelitian yang telah dilakukan yaitu:

a. Konsentrasi maksimum penyerapan kadmium (Cd) oleh tanaman puring sebesar 1,065 $\mathrm{mg} / \mathrm{Kg}$ yang terjadi pada hari ke-9.

b. Tanaman puring (Codiaeum variegatum) tidak termasuk tanaman hiperakumulator untuk logam kadmium (Cd) karena hanya mampu menyerap logam kadmium (Cd) sebesar 1,065 $\mathrm{mg} / \mathrm{Kg}$ dalam 0,002 Kg sampel kering pada asap rokok jenis non filter.

\section{DAFTAR PUSTAKA}

Abdullah bin Muhammad. Lubaabut Tafsiir Min Ibni Katsiir. terj. Abdul Ghoffar, Tafsir Ibnu Katsir. Bogor: Pustaka Imam Asy-Syafi'I, 2004.

Amalia, Nur, Syamsidar HS dan Kurnia Ramadani. "Biosorpsi Tanaman Puring (Codiaeum variegatum) terhadap Emisi Timbal ( $\mathrm{Pb}$ ) pada Kendaraan Bermotor". Jurnal (2014).

Andika, Boni dkk. "Studi Penyerapan Timbal (Pb) Menggunakan Kayu Apu (Pistia stratiotes L) Pada Air Permukaan Sungai Cisadane Kota Tangerang". Laporan Lomba Karya Ilmiah. Pandeglang: SMAN (2009).

Arisusanti, Ratna Juwita dan Kristanti Indah Purwani. "Pengaruh Mikoriza Glomus fasciculatum terhadap Akumulasi Logam Timbal $(\mathrm{Pb})$ pada Tanaman Dahlia pinnata". Jurnal Sains dan Seni Pomits, 2 no. 2 (2013), 
Dewi, Yusriani Sapta dan Indri Hapsari. "Kajian Efektivitas Daun Puring (Codiaeum variegatum) dan Lidah Mertua (Sansevieria trispasciata) dalam Menyerap Timbal di Udara Ambien”. Jurnal Ilmiah Universitas Satya Negara Indonesia. 5 no. 2 (Desember 2012).

Fahrosi, Alfian. "Perbedaan Tingkat Pengetahuan tentang Bahaya Merokok pada Remaja SMP di Pedesaan dan Perkotaan di Kabupaten Jember". Skripsi. Jember: Program Studi Ilmu Keperawatan Universitas Jember, 2013.

S.M, Khopkar. Basic Concepts of Analytical Chemistry, terj. A. Saptorahardjo, Konsep Dasar Kimia Analitik. Jakarta: UI-Press, 2010.

Sumenda, Lusia dkk. "Analisis Kandungan Klorofil Daun Mangga (Mangifera indica L.) pada Tingkat Perkembangan Daun yang Berbeda". Jurnal Biologi (Maret 2011).

Suryani, Tri Vivi. “Galeri Puring 104 Jenis Pilihan”. Jakarta: Penebar Swadaya, 2010.

Tyas, Pining Suwardining, Dwi Setyati dan Umiyah. "Perkembangan Pembungaan Lengkeng (Dimocarpus longan L.)”. Jurnal Ilmu Dasar, 14 no. 2 (Juli 2013).

Wardani, A. Reskianti. "Fitoremediasi Tanaman Rumput Benggala (Panicum maximum Jacq)". Skripsi. Makassar: Fakultas Sains dan Teknologi UIN Alauddin Makassar. 2014.

Widowati, Wahyu, dkk. Efek Toksik Logam: "Pencegahan dan Penanggulangan Pencemaran". Yogyakarta: ANDI, 2008. 